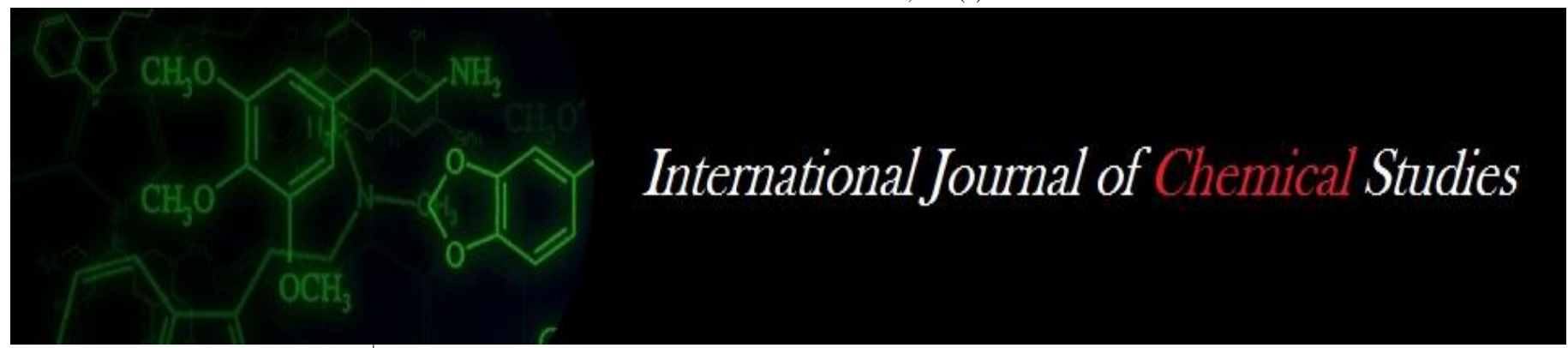

P-ISSN: 2349-8528

E-ISSN: 2321-4902

www.chemijournal.com

IJCS 2020; SP-8(5): 272-274

(C) 2020 IJCS

Received: 15-06-2020

Accepted: 18-09-2020

Rajiv Kumar Varma

Assistant Engineer, Energy

Efficiency Service Limited,

Lucknow, India
Corresponding Author: Rajiv Kumar Varma Assistant Engineer, Energy Efficiency Service Limited, Lucknow, India

\section{Renewable energy: The future of Indian power sector}

\section{Rajiv Kumar Varma}

DOI: https://doi.org/10.22271/chemi.2020.v8.i5e.10634

\begin{abstract}
India, the world's fastest-growing economy having population of more than 1.4 billion, will play the vital role in the future of the global energy markets. Sensing the requirement of energy, the Government of India has made impressive progress in recent years in facilitating citizens' access to electricity and clean cooking. The Govt. of India has also implemented numerous energy market reforms successfully and carried out a huge amount of renewable electricity deployment. Forwarding ahead, the government has laid out an ambitious vision of providing affordable and sustainable energy to all its citizens. This indepth research is to support the energy utilities with a focus on energy security and energy affordability. Keyword: IREDA (Indian Renewable Energy Development Agency Limited), MNRE (Ministry of New and Renewable Energy), CEA (Central Electricity Authority), TPES (Total Primary Energy Supply), TFC (Total Final Consumption), IEA (International Energy Agency), MW (Mega Watt), GW (Giga Watt).
\end{abstract}

Keywords: Renewable energy, Indian power sector

\section{Introduction}

In India, the use of renewable energy sources is poised to grow significantly within the Indian power system. As on 31.08.2020, India $372 \mathrm{GW}$ of installed capacity out of which $88.8 \mathrm{GW}$ is installed under renewable power installed capacity. The Govt. of India has a vision of installing $175 \mathrm{GW}$ of renewable energy capacity by 2022 . Out of this $175 \mathrm{GW}, 60 \mathrm{GW}$ of wind and $100 \mathrm{GW}$ of solar is to be installed by 2022 which was $29 \mathrm{GW}$ wind and $9 \mathrm{GW}$ solar in the beginning of 2017. India's nationally determined contribution emphasizes this ambition to $40 \%$ non-fossil fuels-based electricity generation capacity by 2030 (250-300 GW of solar and wind capacity depending on load). To achieve this target, the Ministry of Power has undertaken numerous initiatives to facilitate renewable power integration at such large scale. Global experience demonstrates that power generation systems can integrate renewable power at this scale, but that evidence-based planning facilitate this integration at least cost. Reform of India's electricity sector will need to be comprehensive to achieve these goals. This report describes a large-scale study of the Indian power system so that the potential impacts of renewable power can be rigorously calculated and serve as the basis for decision-making. The below mention figure shows the share of renewable energy in TPES, electricity \& TFC from 1977- 2017. From the above figure, we can say that the share of renewables in India's energy system has fallen for decades, except in electricity/ power generation where the growth in renewables has kept up with the increase in capacity.

\section{Mainstream technologies of Renewable Energy}

1. Wind energy: Wind energy is the front runner in harnessing the available renewable energy resource due to its financial viability. In India, the expansion of the wind industry has resulted in a strong ecosystem, project operation capabilities and manufacturing base of about 10,000 MW per annum. Wind energy technologies include offshore wind mill, onshore wind mill installed. The govt. of India is providing various incentives for achieving the target of $65 \mathrm{GW}$ of installed capacity by 2022, like Accelerated Depreciation benefit; concessional custom duty exemption on certain components of wind electric generators, waiving off the inter-state transmission charges and losses for wind and solar projects 
to be commissioned by March, 2022, tariff Based Competitive Bidding Process for Procurement of Power.

2. Solar energy: Solar energy is the most attractive renewable energy field for the investment by the private players in India. Solar energy technologies include solar photovoltaic, solar thermal, solar pond, solar street lights, solar lantern, solar agriculture pumps, solar cookers etc. National Institute of Solar Energy has assessed the India's solar potential of about $748 \mathrm{GW}$ with assuming $3 \%$ of the waste land area to be covered by Solar PV modules. The Govt. of India targets for installation of 100 GW grid-connected solar power plants by the year 2022 . In order to achieve the above target, Govt. of India has taken various initiatives like launching of various schemes like Solar Park Scheme, CPSU Scheme, Defence Scheme, Canal bank \& Canal top Scheme, Bundling Scheme, Grid connected solar rooftop scheme etc. and policy measures like solar Renewable Purchase Obligation, Waiver of Inter State Transmission System charges and losses for inter-state sale of solar and wind power for projects to be commissioned up to March 2022, guidelines for the procurement of solar power though tariff based bidding process and guidelines for development of smart cities, Infrastructure status for solar projects, Raising tax free solar bonds, Providing long tenure loans through multi-lateral agencies, etc. to encourage generation of solar power in the country. Presently, solar tariff in India is very competitive and has achieved grid parity.

3. Small hydro power: In India, hydro power plants of $25 \mathrm{MW}$ or below capacity are classified as small hydro, which is considered as renewable power. The estimated potential from 7135 sites for power generation from small / mini hydel projects is assessed as 21135.37 MW by the Alternate Hydro Energy Centre (AHEC) of IIT Roorkee in its Small Hydro Database of July 2016. MNRE emphasis on promoting the use of new and efficient designs of water mills for power generation and setting up of micro hydel projects up to $100 \mathrm{KW}$ for remote village electrification. These projects are taken up with the help of local organizations such as the Water Mills Associations, cooperative societies, registered NGOs, village energy cooperatives, and State Nodal Agencies. As on 31.08.2020, total installed capacity of small hydro power generation is $4.74 \mathrm{GW}$.

4. Biomass energy: Due to the benefits offered by biomass, it has always been an important energy source for the country. This renewable energy source is widely available and has the potential to provide significant employment in the rural areas. In India about $32 \%$ of the total primary energy use is still derived from biomass and more than $70 \%$ of the population depends upon it for its energy needs. MNRE has launched Biomass power \& cogeneration programme with the main objective of promoting technologies for optimum use of country's biomass resources for grid power generation. The main biomass material includes bagasse, coconut shells, soya husk, coffee waste, jute wastes, rice husk, straw, cotton stalk saw dust. As on 31.08.2020, total installed capacity of bio power generation is $10.14 \mathrm{GW}$. The govt. of India is also providing financial assistance in the form of subsidy as Rs. 25 lakh per MW for bagasse co-generation projects \& Rs. 50 lakh per MW for non-bagasse cogeneration projects for promoting the biomass power generation.

5. Waste to energy: With growing demand \& population, various forms of waste are generated from our daily or industrial activities such as organic waste, e-waste, hazardous waste, inert waste etc.. These wastes could be classified as bio degradable or non-bio degradable waste. With the technological advancement, substantial quantity of decentralized energy can be produced along with reducing the quantity of waste for its safe disposal by the process of gasification/ incineration. The total estimated energy generation potential from urban and industrial waste in India is approximately $5690 \mathrm{MW}$. As on 31.08.2020, India has 168.64 MW of installed power generation from waste to energy.

6. Ocean energy/ tidal energy: As per a study conducted by the Indian Institute of Technology, Chennai in December 2014, the tidal power in India has estimated potential of around 12,455 MW. The main potential areas include the Gulf of Khambat, Palk Bay- Mannar Channel in Tamil Nadu, Gulf of Kutch, Hoogly river, Sunderbans \& South Haldia in West Bengal.

7. Hydrogen Energy: In India, the technological development for harnessing the available hydrogen energy potential in India is in development stage. In the field of transportation, major work has been supported to Banaras Hindu University, IIT Delhi, and Mahindra \& Mahindra. Govt. of India has established Two hydrogen refueling stations (one each at Indian Oil R\&D Centre, Faridabad and National Institute of Solar Energy, Gurugram) for R\&D related to hydrogen energy.

8. Geothermal Energy: India has a good potential for geothermal of about 10,600 MW of power. Thermax, a capital goods manufacturer based in Pune, has entered an agreement with Icelandic firm Reykjavík Geothermal for setting up a $3 \mathrm{MW}$ pilot project in Puga Valley, Ladakh (Jammu \& Kashmir). The potential geothermal sites in India are Puga Valley $(\mathrm{J} \& \mathrm{~K})$, Tatapani (Chhattisgarh), Godavari Basin, Unai (Maharashtra), Jalgaon (Maharashtra), Manikaran (Himachal Pradesh), Bakreshwar (West Bengal), Tuwa (Gujarat).

9. Energy storage: Now days, energy storage field is one of the major concentration for private as well as government utilities. Energy storage can play a vital role in grid integration. This would also allow for minimization of diesel consumption from back-up power applications. On the other hand, Energy storage is the main part of EVs in terms of cost and performance determination both.

\section{Government initiatives}

Govt. of India has taken various measures and initiatives for supporting the renewable power generation to harness the available resources for a sustainable \& affordable power availability to meet the citizen's energy demand. Some of the main initiatives are:

- Renewable purchase obligation for power distribution utilities. 
- Generation based incentives, given to the renewable power generators.

- Accelerated Depreciation given on renewable power plants.

- Waiving off of Inter State Transmission System charges and losses for inter-state sale of solar and wind power for projects to be commissioned up to March 2022.

- Standards for deployment of Solar Photovoltaic systems and devices

- $\quad$ Providing long tenor loans from multi-lateral agencies

\section{The Way forward}

The Govt. of India has set ambitious renewable electricity targets for the short to long term. By 2022 the Govt. of India aims to setup $175 \mathrm{GW}$ of installed renewable electricity capacity. In 2018 the Govt. of India increased ambition of 227 GW renewable capacity by 2022 and $275 \mathrm{GW}$ by 2027 . At the end of August 2020 grid-connected renewable electricity capacity reached to $88 \mathrm{GW}$, as given below:

\begin{tabular}{|c|c|c|c|c|c|}
\hline \multirow{2}{*}{$\begin{array}{c}\text { Small } \\
\text { Hydro Power }\end{array}$} & \multirow{2}{*}{ Wind Power } & \multicolumn{2}{|c|}{ Bio-Power } & \multirow{2}{*}{ Solar Power } & \multirow{2}{*}{$\begin{array}{c}\text { Total } \\
\text { Capacity }\end{array}$} \\
\hline & & BM Power/Cogen. & Waste to Energy & & \\
\hline 4739.97 & 37999.55 & 10145.92 & 168.64 & 35739.35 & 88793.43 \\
\hline
\end{tabular}

*source: CEA

Solar PV has witnessed a rapid rise in recent years. To increase investment in renewable electricity in a cost-effective way, India has introduced national competitive auctions for wind and solar PV. At the United Nations' Climate Summit in
New York on 23 September 2019, the Prime Minister of India announced a new target of $450 \mathrm{GW}$ of renewable electricity capacity, without specifying a date.

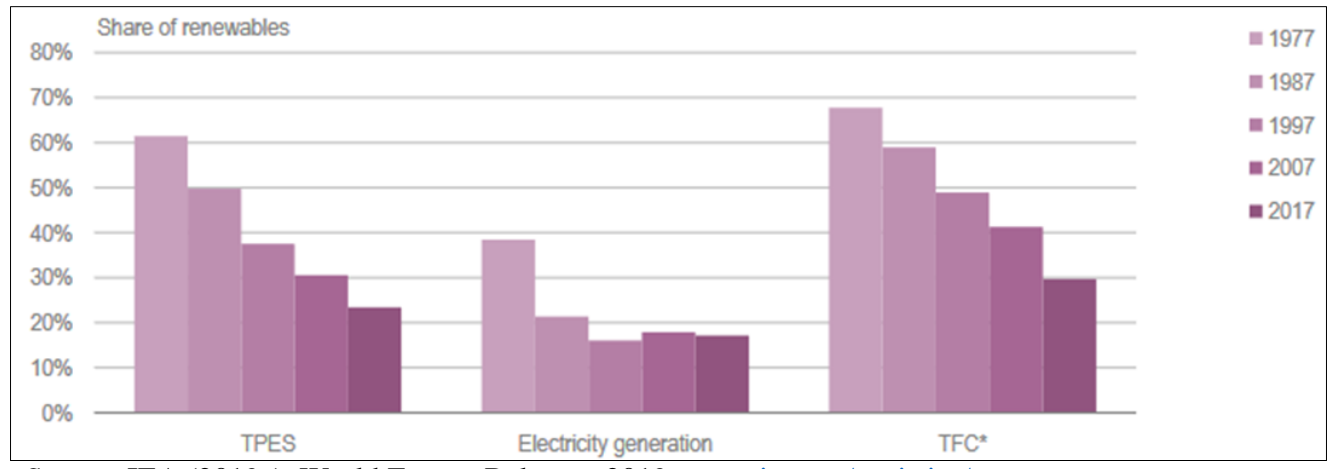

Source: IEA (2019a), World Energy Balances 2019, www.iea.org/statistics/

Fig 1: World Energy Balances 2019

\section{Conclusion}

For providing energy security to all in such a big country having population more than 1.4 billion, the Govt. of India envisage the way to harness the available wide renewable energy sources in India. As the research shows, there is a paradigm shift in the renewable power generation in past decade. Now a days, due to tariff based competitive bidding process \& government initiatives, the renewable power is also become affordable $\&$ it is also giving tariff based competition to thermal power generation. As the tariff of wind power has reached at a level of Rs. 3 per unit in 2019 from Rs. 5.2 per unit in 2011 and tariff of solar power has come down to Rs. 2.36 per unit in 2020 from Rs. 9.5 per unit in 2011, the sustainability of energy demand meets the affordability of energy demand in India.

Govt. of India along with private players are also taking the participation in exploring the more fields like bio fuel, hydrogen fuel, fuel cells, battery storage etc. to provide energy security to a fastest growing economy i.e. India along with tapping the energy market of India.

\section{References}

1. https://mnre.gov.in/

2. https://cea.nic.in

3. https://www.ireda.in

4. https://nise.res.in/

5. https://niwe.res.in/

6. https://nibe.res.in
7. IEA report- India 2020

8. India Energy Policy, 2020 by NITI Aayog 